\title{
Synthesis of Carbon coated Silicon Monoxide with double carbon source and its application as anode for Lithium Ion Battery
}

\author{
Wang Li $^{*}$, Lan Zhou, Wenjun Liao \\ Central Academe, Shanghai Electric Group Co., Ltd. Shanghai 200070, China \\ *E-mail: $\underline{361377505 @ q q . c o m}$
}

Received: 3 June 2021 / Accepted: 19 July 2021 / Published: 10 September 2021

\begin{abstract}
The low initial coulombic efficiency and poor cycling performance of commercial SiO limits its largescale business application. The initial coulombic efficiency was increased and the cycling performance was improved significantly of commercial $\mathrm{SiO}$ by coated vitamin $\mathrm{C}$ and carbon nanotubes heated to $950^{\circ} \mathrm{C}$. The prepared $\mathrm{SiO} / \mathrm{C} / \mathrm{CNTs}-2$ delivered excellent performance, which are an initial chargedischarge efficiency of $74.1 \%$, a high reversible capacity of $1335 \mathrm{mAh} / \mathrm{g}$ and a high retention rate of $96.9 \%$ after 120 cycles, and an low average cycle capacity loss of $0.36 \mathrm{mAh} / \mathrm{g}$. However, the initial charge-discharge of uncoated commercial $\mathrm{SiO}$ is $70.6 \%$, the capacity retention rate is $63.1 \%$ after 20 cycles, and the average cycle capacity loss is $29.6 \mathrm{mAh} / \mathrm{g}$. Compared with uncoated commercial $\mathrm{SiO}$, there is significant improvement in application as anode for lithium ion battery.
\end{abstract}

Keywords: Lithium-ion battery, Anode material, Silicon monoxide, Carbon coating, Carbon nanotubes

\section{FULL TEXT}

(C) 2021 The Authors. Published by ESG (www.electrochemsci.org). This article is an open access article distributed under the terms and conditions of the Creative Commons Attribution license (http://creativecommons.org/licenses/by/4.0/). 